\title{
Postpartum HELLP syndrome and subcapsular liver haematoma
}

\author{
Leif Messerschmidt, Lise Lotte Andersen, Morten Beck Sorensen
}

Department of Obstetrics and Gynaecology, Odense University Hospital, Odense, Denmark

\section{Correspondence to} Dr Morten Beck Sorensen, morten.beck.soerensen@rsyd. $\mathrm{dk}$

Accepted 13 February 2014

\section{DESCRIPTION}

A 35-year-old nulliparous woman had labour induced due to mild pre-eclampsia and delivered by caesarean section at $41+3$ weeks of gestation due to lack of progress in labour. Immediately following surgery she developed epigastric pain, tachycardia and a significant drop in haemoglobin interpreted as haemorrhage. She underwent re-laparotomy and minor blood clots were removed. Blood tests revealed sudden severe hepatic dysfunction/haemolysis (alanine transaminase $2737 \mathrm{IU} / \mathrm{L}$, lactate dehydrogenase $3300 \mathrm{IU} / \mathrm{L}$ ) and thrombocytopenia (platelet count $38 \times 10^{9} / \mathrm{L}$ ) consistent with severe $\mathrm{H}$ (haemolysis, the breakdown of red blood cells); EL (elevated liver enzymes) LP (low platelet count) syndrome and she was admitted for intensive care postoperatively. Symptoms from the upper abdomen increased and a transabdominal ultrasound scan revealed a subcapsular liver haematoma. Active bleeding was not suspected and the diagnosis was confirmed by a CT scan (figure 1). It was agreed to treat conservatively after abdominal surgeons and gastroenterologists were consulted and she was stabilised on magnesium sulfate, labetalol and fluid management. After 3 days the patient was transferred to the maternity ward. Her symptoms from the upper abdomen and the haematoma resolved

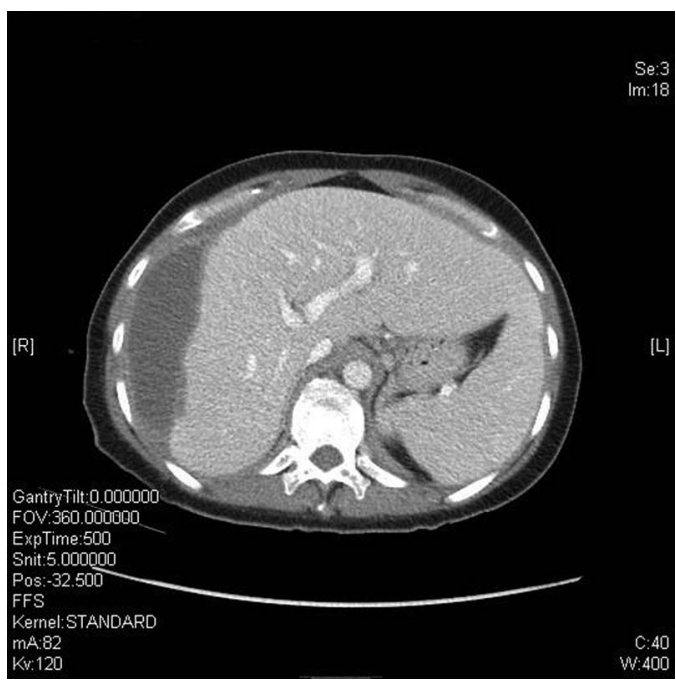

Figure 1 CT scan in the transverse plane of the liver. The image showing a large subcapsular liver infiltrate consistent with a haematoma. spontaneously, over months. Subcapsular liver haematoma is a rare, albeit life-threatening, complication of pregnancy. ${ }^{1}$ The incidence is $1 / 67000$ deliveries. $^{2}$ The symptoms include epigastric pain and possibly circulatory collapse. Surgical management may include drainage, tambonade by packing or hepatic resection. ${ }^{13}$ Conservative management is advocated in non-bleeding patients. ${ }^{2}$ Following improvements in imaging, diagnosis and supportive management, the mortality has decreased. ${ }^{1}$ In this case the unusual timing of the presentation highlights the importance of urgent liver imaging of unusual epigastric symptoms in severe pre-eclampsia —also after delivery.

\section{Learning points}

Subcapsular liver haematoma is a potentially life-threatening complication of severe pre-eclampsia and $\mathrm{H}$ (haemolysis, the breakdown of red blood cells); EL (elevated liver enzymes) LP (low platelet count) syndrome.

- The complication is rare but should be considered with severe upper abdominal pain in obstetric patients, especially in the presence of pre-eclampsia.

- Real-time ultrasound imaging of the liver is often diagnostic.

Contributors LM was involved in the design of the manuscript, drafting the article, analysis and interpretation of the data. LLA was involved in the acquisition of the data, analysis, interpretation of the data and revising it critically for important intellectual content. MBS was involved in the conception of the manuscript, revising it critically for important intellectual content and final approval of the version published.

Competing interests None.

Patient consent Obtained.

Provenance and peer review Not commissioned; externally peer reviewed.

\section{REFERENCES}

1 Vigil-De Gracia P, Ortega-Paz L. Pre-eclampsia/eclampsia and hepatic rupture. Int J Gynecol Obstet 2012;118:186-9.

2 Pavlis T, Aloiozos S, Aravosita P, et al. Diagnosis and surgical management of spontaneous hepatic rupture associated with HELLP syndrome. J Surg Educ 2009;66:163-7.

3 Aranjo $A C$, Leao MD, Nobrega MH, et al. Characteristics and treatment of hepatic rupture caused by HELLP syndrome. Am J Obstet Gynecol 2006;195:129-33. 
Copyright 2014 BMJ Publishing Group. All rights reserved. For permission to reuse any of this content visit http://group.bmj.com/group/rights-licensing/permissions.

BMJ Case Report Fellows may re-use this article for personal use and teaching without any further permission.

Become a Fellow of BMJ Case Reports today and you can:

- Submit as many cases as you like

- Enjoy fast sympathetic peer review and rapid publication of accepted articles

- Access all the published articles

- Re-use any of the published material for personal use and teaching without further permission

For information on Institutional Fellowships contact consortiasales@bmjgroup.com

Visit casereports.bmj.com for more articles like this and to become a Fellow 